\title{
PELINDUNGAN PATEN MELALUI PATENT COOPERATION TREATY DAN REGULATIONS UNDER THE PATENT COOPERATION TREATY \\ PATENT PROTECTION THROUGH PATENT COOPERATION TREATY AND REGULATIONS UNDER THE PATENT COOPERATION TREATY
}

\author{
Novianti \\ Pusat Penelitian Badan Keahlian DPR RI \\ Komplek MPR/DPR/DPD Gedung Nusantara I Lantai 2, \\ Jl. Jenderal Gatot Subroto Jakarta \\ Email: novianti.dpr@gmail.com \\ Naskah diterima: 15 Agustus 2017 \\ Naskah direvisi: 15 September 2017 \\ Naskah diterbitkan: 30 November 2017
}

\begin{abstract}
The development of science and technology, especially the emergence of new inventions, has reduced the limits of space and time. In terms of IPR, it challenges us to protect our IPR under IPR law, both at the national level and international level. However, given the fact that the patent issue was raised locally in each country, it's difficult to uniformize the management and protection of IPR among countries. The problem being raised is that the patent issue is a local issue which is closely intertwined with national sovereignty. Fortunately, there have been efforts to make a technologically-based system in order to integrate the management and protection of IPR at the international level. The system has been successfully made along with the Patent Cooperation Treaty (PCT) and Regulations Under the PCT (RUP). All countries need to ratify them to protect the IPR of their citizens at the international level. This research concerns with the arrangement and implementation of patent protection through PCT and RUP. This research concludes that the international conventions have been made to accommodate and guarantee the legal aspect of the Treaty, such as Trips, PCT and WIPO. As a country which has ratified the Treaty, Indonesia has issued Presidential Decree No. 16 of 1997 which is finalized into Law No. 13 of 2016 on Patents (Article 33), stating that applications may be filed under a Patent Cooperation Treaty. This research also points out that although it's believed that all countries will benefit from PCT and RUP, PCT has not attracted significant numbers of applicants. That means, there is still much work to be done.
\end{abstract}

Keywords: Patent protection, Patent cooperation treaty, Regulations Under the PCT

\begin{abstract}
Abstrak
Perkembangan ilmu pengetahuan dan teknologi, dengan munculnya invensi-invensi baru, menyebabkan batasan ruang dan waktu semakin menipis. Dalam kaitannya dengan IPR, perkembangan tersebut menjadi tantangan untuk mewujudkan perlindungan HKI khususnya paten, baik dalam konteks nasional maupun internasional. Akan tetapi, persoalannya selama ini, sangat sulit melakukan penyeragaman pengaturan perlindungan paten antara satu negara dan negara-negara lainnya. Tiap-tiap negara menerapkan aturan pengelolaan dan pelindungan patennya sendiri dengan alasan bahwa paten merupakan suatu hak eksklusif yang diberikan oleh suatu negara dan karenanya segala hal yang terkait dengan pengelolaannya tidak bisa tidak menyentuh masalah kedaulatan suatu negara. Perkembangan global, terutama perkembangan iptek, memudahkan penyeragaman pengaturan paten secara internasional sekaligus memberikan pelindungan hukum terhadapnya. Hal itu tampak pada tersedianya suatu sistem yang terintegrasi, yang dapat diberlakukan secara seragam di semua negara yang meratifikasinya, yaitu Patent Cooperation Treaty (PCT) and Regulations Under the PCT. Masalah yang menjadi fokus tulisan ini adalah bagaimana pengaturan pelindungan paten melalui PCT dan bagaimana penerapan
\end{abstract}


pelindungan paten melalui PCT. Kesimpulan dari penelitian ini adalah pengaturan pelindungan paten melalui PCT terdapat dalam beberapa konvensi internasional, antara lain pengaturan Trip's, PCT, dan WIPO. Dalam hukum nasional, PCT telah diratifikasi dengan Keppres No. 16 Tahun 1997 dan diatur dalam Pasal 33 UU No. 13 Tahun 2016 tentang Paten, yang menyatakan bahwa permohonan dapat diajukan berdasarkan Traktat Kerja Sama Paten. Dalam penerapannya, permohonan dan pelindungan paten melalui PCT belum menunjukkan perkembangan yang cukup signifikan dan masih banyak ditemukan kendala.

Kata kunci: Pelindungan paten, Patent cooperation treaty, Regulations Under the PCT

\section{PENDAHULUAN}

Pada era globalisasi dewasa ini, tuntutan pengembangan terhadap ilmu pengetahuan dan teknologi menjadi isu utama baik di negara maju maupun negara berkembang agar dapat bersaing guna memenuhi kebutuhan manusia yang selalu dinamis. Teknologi sebagai produk paten telah menjadi salah satu komoditi yang paling strategis dalam perdagangan internasional, di mana teknologi memainkan peranan yang signifikan dalam memenuhi kebutuhan masyarakat. Hal ini disebabkan hampir semua kebutuhan manusia dalam abad modern ini berasal dari produk yang lahir dari kemampuan intelektualitas manusia di bidang ilmu pengetahuan dan teknologi ${ }^{1}$

Perkembangan ilmu pengetahuan dan teknologi (IPTEK) menyebabkan batasan ruang dan waktu semakin menipis dengan terus bermunculannya invensi baru. Hal ini menjadikan Hak Kekayaan Intelektual (HKI) khususnya paten menjadi suatu komoditas hukum yang harus diperhatikan pelindungannya. Dalam praktik perdagangan, dapat dijumpai

Ignatius Haryanto, Penghisapan Rezim HaKI, Tinjauan Ekonomi Politik Terhadap HaKI, Jakarta: Kreas Wacana, 2002, hal.17. berbagai pelanggaran paten, salah satu contoh yakni kasus gugatan perusahaan Paice kepada produsen mobil asal Korea Selatan, HYUNDAI dan KIA. Di era teknologi ramah lingkungan seperti saat ini, mobil dua mesin alias hybrid sudah diproduksi oleh hampir semua pabrikan otomotif yang ada. Namun, Hyundai dan KIA harus menghadapi permasalahan karena dituduh melanggar hak paten teknologi hybrid dari sebuah perusahaan karena dianggap telah memakai sistem hybrid yang patennya mereka pegang. Dengan demikian, untuk mengatasi adanya pelanggaran paten tersebut diperlukan pelindungan hukum terhadap pemegang paten.

Pelindungan terhadap pemegang paten, pada dasarnya hanya bersifat teritorial artinya paten tersebut hanya berlaku untuk satu wilayah tertentu dan jika ingin diakui di negara luar maka ia harus mendaftarkan kembali patennya di negara tersebut. Ini artinya paten asing apabila ingin mendapatkan pelindungan di Indonesia, maka terlebih dahulu harus mengajukan permohonan kepada Menteri secara tertulis. Dengan demikian paten menganut prinsip teritorial, artinya pelindungan paten hanya berlaku di negara di mana permohonan paten diajukan dan diberi. Untuk memperoleh pelindungan paten di wilayah hukum Indonesia, maka inventor harus mengajukan permohonan paten di Indonesia, Di sisi lain inventor yang hanya mematenkan invensinya di Indonesia, tidak memiliki hak paten di negara lain.

Masalah pelindungan paten sudah merupakan suatu topik yang bersifat internasional yang melampaui batas negara sehingga diperlukan suatu ketentuan yang dapat di implementasikan ke banyak negara dan tidak bertentangan dengan peraturan yang berlaku dalam suatu negara. Karena tiap negara mempunyai kedaulatan untuk mengatur masalah pelindungan paten, maka hal tersebut menimbulkan ketentuan yang berbeda antara satu negara dengan negara lainnya dan supaya terdapat suatu harmonisasi dalam bidang pelindungan paten tersebut, maka dalam perkembangannya diciptakanlah Patent Cooperation Treaty (PCT). PCT merupakan suatu ketentuan atau cara untuk mempermudah 
proses permohonan paten di berbagai negara. Sebelum diberlakukannya PCT, bukan berarti seorang inventor tidak dapat mendaftarkan invensinya ke berbagai negara. Sejak dahulu sudah berlaku ketentuan atau cara permohonan paten yang memungkinkan inventor untuk mendaftarkan invensinya ke berbagai negara. Namun ketentuan atau cara tersebut dianggap masih mempunyai kekurangan sehingga diciptakan $\mathrm{PCT}^{2}$.

Perkembangan IPTEK sebuah negara juga dapat dilihat dari jumlah paten yang sudah didaftarkan di Ditjen Hak Kekayaan Intelektual (Ditjen HKI) ataupun Patent Cooperation Treaty (PCT). Semakin banyak jumlah paten yang didaftarkan oleh satu negara, maka dapat dilihat seberapa banyak hasil teknologi yang sudah ditemukannya. ${ }^{3}$ Perlu dipahami bahwa paten merupakan salah satu bagian dari HKI atau Intellectual Property Rights. Ditjen HKI mendefinisikan HKI sebagai hak yang timbul dari hasil olah pikir otak yang menghasilkan suatu produk atau proses yang berguna untuk manusia. ${ }^{4}$

Indonesia ikut serta menandatangani PCT antarnegara di Amerika Serikat Tahun 1970. PCT tersebut disahkan berdasarkan Keputusan Presiden Nomor 16 Tahun 1997 tentang Pengesahan Patent Cooperation Treaty and Regulations under the PCT. Tindakan ratifikasi yang dilakukan Indonesia terhadap PCT dimaksudkan agar dapat memberikan pelindungan yang wajar bagi inventor dan menciptakan iklim usaha yang jujur serta memperhatikan kepentingan masyarakat. Pelindungan paten yang baik ditandai dengan tersedianya perangkat peraturan yang lengkap di bidang paten serta penegakan hukum yang memuaskan. Proses reformasi ke arah tersebut diawali dengan diratifikasinya perjanjian

\footnotetext{
"Peranan Patent Cooperation Treaty (PCT) Dalam Permohonan Paten di Indonesia", http://etd.repository. ugm.ac.id/index.php? $\bmod =$ penelitian_detail\&sub $=$ Pen elitianDetail\&act $=$ view $\&$ typ $=$ html\&buku_ii $=69220$, diakses 25 Agustus 2017.

Khoirul Hidayah, "Perlindungan Hak Paten Dalam Kajian Hukum Islam dan Peran Umat Islam Dalam Bidang IPTEK", de Jure, Jurnal Syariah dan Hukum, Volume 4 Nomor 1, Juli 2012, hal. 86
}

$4 \quad$ Ibid dengan World Intellectual Property Organization (WIPO) yaitu badan Perserikatan BangsaBangsa yang menangani urusan hak kekayaan intelektual pada tahun 1979. WIPO telah lama merancang sistem global untuk memfasilitasi mendapatkan pelindungan paten melalui sistem PCT. PCT merupakan suatu sistem global yang dirancang untuk memfasilitasi proses perolehan pelindungan paten di banyak negara. Adapun manfaat fasilitas PCT yakni dengan hanya mengajukan satu permohonan pelindungan internasional paten melalui PCT, maka inventor atau kalangan pengusaha swasta Indonesia bisa mendapatkan pelindungan hukum atas patennya di banyak negara sesuai dengan keinginan pemohon dengan syarat negara tersebut harus menjadi anggota PCT dan Indonesia merupakan salah satu dari anggota PCT karena telah meratifikasi PCT.

Terkait dengan pelindungan paten melalui PCT, terdapat permasalahan yakni bagaimana penerapan perjanjian internasional (PCT dan Regulations under the PCT) ke dalam hukum nasional. Hal tersebut dikarenakan perbedaan perspektif dalam memandang kedudukan perjanjian internasional (PCT) dalam hukum nasional. Perbedaan perspektif ini kemudian melahirkan inkonsistensi dalam penerapan perjanjianinternasional kedalamhukumnasional. Selain itu, suatu negara harus memastikan bahwa pentaatan perjanjian internasional mendapat justifikasi dari hukum nasionalnya. $\mathrm{Di}$ lain pihak, bagaimana perjanjian internasional ditransformasikan, diadopsi, dan diperingkatkan dalam hukum nasional adalah urusan hukum nasional. Permasalahan lainnya terkait dengan pelindungan paten adalah kurangnya informasi yang diperoleh stakeholder HKI mengenai sistem PCT. Permasalahan lain yakni terkait dengan International Pleminary Examination Report (IPER) tidak bersifat mengikat. Dengan demikian, hak untuk menolak atau mengabulkan permohonan permintaan paten tetap berada di negara masing-masing ${ }^{5}$

\footnotetext{
Soedjono Dirdjosiswono, Hukum Perusahaan Mengenai Hak Atas Kekayaan Intelektual (Hak Cipta, Hak Paten, Hal Merek), Bandung: Mandar Maju, 2000, hal. 333.
} 
Implikasi lainnya terhadap keiikutsertaan Indonesia dalam berbagai konvensi internasional di bidang HKI termasuk PCT, Indonesia telah mengimplementasikan sistem paten melalui undang-undang yang mengatur tentang paten. Sejarah kelahiran paten di Indonesia berawal pada tahun 1910 di mana Indonesia diberikan pengaturan paten berdasarkan undangundang kolonial Belanda yang dinamakan Octroiiwet. Setelah kemerdekaan, pada tahun 1979 Indonesia meratifikasi perjanjian dengan WIPO dan pada tahun 1983, Indonesia masuk menjadi anggota Paris Convention. Selanjutnya tahun 1989 Dewan Perwakilan Rakyat (DPR) mengesahkan Undang-Undang Nomor 6 Tahun 1989 tentang Paten yang kemudian mengalami perubahan menjadi Undang-Undang Nomor 13 Tahun 1997 tentang Paten. Pada tahun 2001, pemerintah memperbaharui undangundang paten menjadi Undang-Undang Nomor 14 Tahun 2001 dan terakhir dilakukan penggantian menjadi Undang-Undang Nomor 13 Tahun 2016 tentang Paten. Hal tersebut dilakukan karena Indonesia harus menyesuaikan pelindungan HKI dengan standar internasional dan sebagai implikasi keikutsertaan Indonesia dalam beberapa konvensi internasional terkait dengan pelindungan paten sebagaimana telah dijelaskan. Selain itu, penggantian UU Paten Tahun 2001 juga dilatar belakangi peningkatan pelindungan paten sangat penting bagi inventor dan pemegang paten karena dapat memotivasi inventor untuk meningkatkan hasil karya, baik secara kuantitas maupun kualitas untuk mendorong kesejahteraan bangsa dan negara. Oleh sebab itu, pada 26 Agustus 2016 diundangkanlah UU Paten yang baru yakni Undang-Undang Nomor 13 Tahun 2016 tentang Paten (UU Paten Tahun 2016). Dengan diundangkannya UU Paten Tahun 2016 tersebut maka Indonesia masuk dalam era pelindungan paten yang baru. UU Paten yang baru ini diharapkan dapat memberikan pelindungan yang lebih baik serta lebih sesuai dengan standar yang ada didalam The Agreement on Trade-Related Aspects of Intellectual Property Rights (TRIP's.). Salah satu urgensi yang diatur dalam UU Paten Tahun 2016 adalah adanya penyesuaian dengan sistem Otomatisasi Administrasi Kekayaan Intelektual terkait pendaftaran paten dapat diajukan secara elektronik yaitu dilakukan dengan sistem IPAS (Industrial Property Automation System). Selain itu, terdapat pengaturan lebih lanjut terkait pendaftaran paten berdasarkan permohonan melalui PCT. UU Paten Tahun 2001 tidak mengatur secara jelas bagaimana sistem pendaftaran melalui PCT tersebut dapat dilakukan.

Ketentuan tentang permohonan paten melalui PCT diatur dalam Pasal 33 UU Paten Tahun 2016 yang menyatakan bahwa permohonan dapat diajukan berdasarkan Traktat Kerja Sama Paten (PCT). Ketentuan ini bermaksud untuk memberikan kemudahan dan kecepatan kepada seorang pemohon di Indonesia dalam mengajukan permohonannya di negara yang merupakan anggota PCT, demikian juga sebaliknya bagi anggota dari negara lain yang tergabung dalam PCT dapat diselesaikan secara mudah dan cepat.

Berdasarkan latar belakang tersebut, permasalahan pokok dalam penelitian ini adalah bagaimana pelindungan paten melalui PCT dan Regulations under the PCT? Berdasarkan permasalahan pokok tersebut beberapa pertanyaan yang diajukan adalah 1) bagaimana pengaturan pelindungan paten melalui PCT dan Regulations under the PCT; 2) bagaimana penerapan pelindungan paten melalui PCT dan Regulations under the PCT serta kendala-kendalanya?

Tujuan penulisan ini adalah 1) mengetahui pengaturan pelindungan paten melalui PCT dan Regulations under the PCT; dan 2) untuk mengetahui penerapan pelindungan paten melalui PCT dan Regulations under the PCT serta kendalakendalanya. Penulisan artikel ini diharapkan dapat digunakan sebagai bahan masukan bagi DPR RI dalam melakukan pengawasan terhadap UU Paten Tahun 2016. Selain itu, artikel ini diharapkan dapat bermanfaat sebagai sumbangan pemikiran terhadap pengembangan ilmu pengetahuan di bidang hukum, khususnya di bidang pelindungan paten. 
Karya tulis ilmiah berkaitan dengan pelindungan paten melalui PCT, antara lain:

1. Jurnal yang berjudul "Peranan Patent Cooperation Treaty (PCT) DalamPermohonan Paten Di Indonesia". Jika dicermati penelitian yang dilakukan oleh Berti Deliani menganalisa bagaimana peranan PCT dalam proses permohonan paten di Indonesia dan untuk mengetahui dampak yang ditimbulkan terhadap perkembangan hukum paten di Indonesia. HKI merupakan salah satu faktor yang dapat mendorong perkembangan suatu masyarakat dan HKI tersebut merupakan satu bagian dari ilmu pengetahuan dan teknologi. Dampak dari perkembangan tersebut adalah timbulnya perbedaan pengaturan pelindungan paten antara satu negara dengan negara lainnya, namun karena paten tersebut pada hakikatnya adalah suatu hak eksklusif oleh karena itu sangat sulit untuk melakukan penyeragaman pengaturan pelindungan paten antara satu negara dengan negara lainnya. Untuk itulah diperlukan suatu cara atau sarana yang dapat mengakomodir perkembangan iptek memberikan pelindungan hukum terhadapnya. Adapun kesimpulan dari tulisan ini adalah dengan PCT dapat meningkatkan permohonan pelindungan paten asing di Indonesia yang berdampak pada peningkatan pendapatan ekonomi Indonesia. Selain itu PCT juga memfasilitasi sarana untuk memudahkan para inventor atau pemohon untuk mengajukan permohonan paten ke berbagai negara anggota yang ia kehendaki. Dengan ketentuan yang terintegrasi dalam PCT, para pemohon, pihak yang berkepentingan, dan negara anggota yang menjadi tujuan akan dapat dengan mudah mengakses informasi permohonan yang diajukan, terlebih dengan adanya fasilitas internet. Sementara tulisan "Pelindungan Paten Melalui Patent Cooperation Treaty (PCT) and Regulations under The PCT" ini melihat dari aspek lain yakni lebih pada pelindungan paten melalui PCT dan Regulations Under the PCT sebagai negara yang sudah meratifikasi PCT dan analisisnya fokus pada hukum internasional dan hukum nasional yakni menganalisa pengaturan pelindungan paten melalui PCT yang terdapat dalam hukum internasional dan hukum nasional. Selain itu juga menganalisa penerapan pelindungan paten melalui PCT dan menganalisa beberapa kendala yang timbul dalam penerapannya.

2. Jurnal yang berjudul "Perlindungan Terhadap Paten Asing Berdasarkan Sistem Hukum Paten di Indonesia Pasca TRIPS WTO”. Penelitian hukum yang ditulis oleh Kurniawan, mencermati beberapa persoalan terkait dengan pelindungan terhadap paten yakni menganalisa bagaimana perlindungan hukum terhadap paten asing di Indonesia dan tata cara permohonan pendaftaran paten asing berdasarkan sistem hukum paten di Indonesia serta bagaimana pelaksanaan paten asing yang telah didaftarkan di Indonesia paska TRIPs-WTO. Sementara tulisan "Pelindungan Paten Melalui Patent Cooperation Treaty (PCT) and Regulations under The PCT" ini melihat dari aspek lain yakni lebih ke pelindungan paten melalui PCT dan Regulations under the PCT.

3. Jurnal yang berjudul "Implikasi Paten Asing Yang Telah Terdaftar Atas Invensi Di Bidang Teknologi Menurut UndangUndang No 14 Tahun 2001 Tentang Paten". Tulisan yang ditulis oleh Edwar James Sinaga, mencermati persoalan terhadap pelindungan hukum terhadap hasil invensi di bidang teknologi yang diharapkan dapat merangsang inventor untuk lebih kreatif dan inovatif dalam menemukan berbagai invensi di bidang teknologi terutama bagi inventor-inventor asing yang mendominasi pendaftaran paten di Indonesia. Persoalan lain yakni terkait dengan prosedur dan syarat-syarat hukum paten Indonesia yang sering tidak terpenuhi oleh pemohon paten asing dan implikasi pelindungan hukum dan penegakan hukum paten asing bagi Indonesia sebagai peserta PCT. Sedangkan tulisan "Pelindungan Paten Melalui Patent Cooperation Treaty (PCT) and Regulations 
under The PCT" ini melihat dari aspek lain yakni lebih ke pelindungan paten melalui PCT dan Regulations under the PCT yakni menganalisa pengaturan pelindungan paten melalui PCT yang terdapat dalam hukum internasional dan hukum nasional. Selain itu juga menganalisa penerapan pelindungan paten melalui PCT dan kendala-kendalanya serta analisisnya fokus pada hukum internasional dan hukum nasional.

\section{METODE PENELITIAN}

Penelitian ini merupakan penelitian yuridis normatif dan yuridis empiris. Penelitian yuridis normatif dilakukan terhadap peraturan perundang-undangan yang berkaitan dengan pengaturan PCT terkait dengan pelindungan paten. Sedangkan penelitian yuridis empiris dilakukan untuk mengetahui penerapan PCT terkait dengan pelindungan paten.

Metode pendekatan yang digunakan adalah pendekatan kualitatif, dengan melakukan studi kepustakaan terlebih dahulu. Studi kepustakaan dilakukan untuk mengumpulkan data sekunder, berupa peraturan perundangundangan terkait peranan PCT. Selain itu, data sekunder juga berupa ulasan atau pendapat para pakar yang terdapat dalam buku, karya tulis ilmiah, dan jurnal, termasuk yang dapat diakses melalui internet. Sedangkan data primer diperoleh dari narasumber atau informan pihakpihak yang berkompeten, yaitu Pemerintah Provinsi (Pemrov), Kanwil Hukum dan HAM, Dinas Perindustrian, LSM, dan akademisi, dalam penelitian tentang Pelindungan Paten Melalui PCT yang dilakukan pada tahun 2017. Penelitian lapangan ke daerah dilaksanakan di Provinsi Bali dan Provinsi Sumatera Barat. Selanjutnya, data yang terkumpul, baik data primer maupun data sekunder, dianalisis dengan metode kualitatif. Analisis yuridis deskriptif menggambarkan kerangka regulasi (pengaturan atau norma-norma) mengenai PCT terkait dengan pelindungan paten.

\section{PENGATURAN PERLINDUNGAN PATEN}

Dalam melihat pengaturan hukum internasional ke dalam hukum nasional yakni pengaturan pelindungan paten melalui PCT dan Regulations under the PCT terdapat dua teori yang menjelaskan pengaturan tersebut yakni teori monisme dan teori dualisme ${ }^{6}$. Adapun teori monisme berpandangan bahwa hukum internasional adalah konsekuensi langsung dari norma dasar seluruh hukum sehingga mengikat setiap individu secara kolektif. Oleh karena pemikiran tersebut melihat hukum internasional dan hukum nasional sebagai satu kesatuan 'tubuh' pengetahuan yang dinamakan hukum, maka monisme menggunakan teknik incorporation di mana negara dapat menerapkan hukum internasional di wilayah nasional tanpa mengubah dasar hukumnya. Teknik incorporation memberi implikasi terciptanya jenis treaty yakni self-executing treaty yang bersifat dapat diterapkan secara langsung dalam sistem hukum nasional.

Sedangkan teori dualisme ${ }^{7}$ memberi supremasi pada hukum nasional berdasarkan kedaulatan negara sehingga hukum internasional tidak dapat memaksa suatu negara patuh terhadap hukum internasional. Berbeda dengan teori monisme yang melihat hukum internasional sebagai satu kesatuan dengan hukum nasional, teori dualisme menempatkan hukum internasional terpisah dengan hukum nasional. Oleh karenanya terdapat pemisahan tegas antara kedua jenis hukum tersebut, maka teori dualisme menggunakan teknik transformation di mana penerapan hukum internasional harus diikuti dengan proses legislasi untuk mengubah hukum internasional menjadi bagian dari hukum nasional. Teknik transformasi ini menghasilkan jenis hukum yang bersifat nonself-executing treaty di mana jenis tersebut tidak akan memiliki daya ikat tanpa aturan tambahan

Damos Dumoli Agusman, Treaties Under Indonesian Law: A Comparative Study, Jakarta: Remaja Rosdakarya, 2014, hal 85.

Firdaus, "Kedudukan Hukum Internasional Dalam Sistem Perundang-undangan Nasional Indonesia”, Fiat Justisia, Jurnal Ilmu Hukum, Volume 8 Nomor 1, Januari-Maret 2014, hal. 43. 
atau aturan pelaksana nasional. Kedua teori klasik tersebut berdasarkan teori delegasi dijelaskan bahwa aturan hukum internasional mendelegasikan kepada masing-masing konstitusi negara, hak untuk menentukan kapan ketentuan perjanjian internasional berlaku dalam hukum nasional dan cara bagaimana ketentuan perjanjian internasional dijadikan hukum nasional. Praktek Indonesia terkait dengan penerapan teori tersebut cenderung tidak konsisten sehingga menjadi perdebatan di kalangan pakar hukum internasional. Praktek Indonesia terkait penerapan hukum internasional ke dalam hukum nasional dapat dilihat dalam Pasal 9 Undang-Undang Nomor 24 Tahun 2000 tentang Perjanjian Internasional yang menyatakan bahwa pengesahan perjanjian internasional oleh pemerintah dilakukan sepanjang dipersyaratkan oleh perjanjian internasional tersebut dan pengesahan terhadap perjanjian internasional dilakukandenganUndang-UndangatauKeputusan Presiden. Dengan demikian pengesahan yang dilakukan menurut hukum nasional Indonesia, merupakan bagian prosedur ratifikasi dalam ranah hukum nasional. Ratifikasi merupakan bagian prosedur pembentukan hukum internasional yang dituangkan dalam perjanjian yang bersangkutan. Keterikatan Indonesia pada perjanjian internasional yang bersangkutan, dilandaskan pada penyampaian instrumen ratifikasi dalam ranah hukum internasional. Apabila Indonesia sudah menjadi negara pihak, Indonesia wajib melaksanakannya dengan itikad baik dan melakukan penyesuaian atau harmonisasi perundang-undangan dengan perjanjian internasional yang sudah berlaku secara definitif.

Penerapan perjanjian internasional khususnya perjanjian kerjasama paten atau PCT ke dalam hukum nasional dalam hal ini menganut teori delegasi yakni dilakukan melalui ratifikasi atau pengesahan dengan Keppres No. 16 Tahun 1997 tentang Pengesahan Patent Cooperation Treaty. Dengan diratifikasinya PCT maka Indonesia wajib untuk menyesuaikan undang-undang yang ada dengan ketentuan yang diatur dalam perjanjian internasional tersebut. Dengan demikian pemberlakuan perjanjian internasional khususnya PCT ke dalam hukum nasional Indonesia tidak serta merta bisa dilakukan, karena harus melalui ratifikasi berupa Keppres pengesahan PCT tersebut. Hal ini juga memperlihatkan bahwa Indonesia memandang hukum nasional dan hukum internasional sebagai dua sistem hukum yang berbeda dan terpisah satu dengan yang lainnya. Olehkarenaitu, perjanjianinternasional berupa PCT harus ditransformasikan menjadi hukum nasional dalam bentuk peraturan perundang-undangan sebagaimana telah diatur dalam Keppres No. 16 Tahun 1997 dan Pasal 33 UU Paten Tahun 2016.

\section{A. Pengaturan Menurut PCT dan Regulations under the PCT}

Menurut WIPO, hak kekayaan intelektual biasanya dibagi menjadi dua bagian, yaitu Hak Cipta (Copy Right) dan Hak Kekayaan Industri (Industrial Property Right). Hak kekayaan industri menurut Pasal 1 Konvensi Paris mengenai Perlindungan Hak atas Kekayaan Industrial tahun 1883 yang telah direvisi dan diamandemen pada 2 Oktober 1979 yang biasa disebut Konvesi Paris, perlindungan hukum kekayaan industri meliputi: 1) Paten 2) Merek 3) Hak Design Industri 4) Nama Perusahaan 5) Indikasi Geografi dan Indikasi Asal. Dalam penelitian ini yang akan dipaparkan adalah mengenai hak kekayaan industri berupa paten ${ }^{8}$. Istilah paten bermula dari bahasa Latin dari kata auctor yang berarti dibuka, maksudnya adalah bahwa suatu penemuan yang mendapatkan paten menjadi terbuka untuk diketahui oleh umum. Dengan terbukanya tersebut tidak berarti setiap orang bisa mempraktekkan penemuan tersebut, hanya dengan izin dari si penemu suatu penemuan bisa didayagunakan oleh orang lain dan baru setelah habis masa perlindungan paten maka penemuan tersebut menjadi milik umum. ${ }^{9}$

\footnotetext{
8 Rinayah Nasir, "Paten Dalam Proses Produksi: Tinjauan Hak Yang Melekat pada Inventor", Jurnal Hukum POSITUM, Volume 1, Nomor 1, Desember 2016, hal. 144.

Endang Purwaningsih, "Paten Sebagai Konstruksi Hukum Perlindungan Terhadap Invensi Dalam Bidang Teknologi dan Industri", Jurnal Hukum Pro Justitia, Volume 24
} 
WIPO $^{10}$ memberi definisi paten sebagai berikut:

"A Patent is legally enforceable right granted by virtue of a law to a person to exlude, for a limited time, others from certain acts in relation to describe new invention; the privilege is granted by a government authority as a matter of right to the person who is entitled to apply for it and who fulfils the prescribed condition".

Pasal 1 angka 1 UU Paten Tahun 2016, mendefinisikan paten sebagai hak eksklusif yang diberkan negara kepada inventor atas hasil invensinya di bidang teknologi, yang untuk selama waktu tertentu melaksanakan sendiri invensinya tersebut atau memberikan persetujuan kepada pihak lain untuk melaksanakannya.

Dari definisi tersebut terdapat beberapa unsur penting yakni:

1. Hak eksklusif merupakan hak yang bersifat khusus. Kekhususannya terletak pada kontrol hak yang hanya ada di tangan pemegang paten. Konsekuensinya, pihak yang tidak berhak tidak boleh menjalankan hak eksklusif tersebut. Hak eksklusif melekat pada pemegang paten.

2. Negara merupakan satu-satunya pihak yang berhak memberikan paten kepada para inventor. Biasanya tugas ini didelegasikan kepada sebuah kantor khusus yang menangani permohonan pendaftaran, pengumuman, pemeriksaan dan pemberian sertifikat paten. Di Indonesia, tugas ini ditangani oleh Direktorat Jenderal Hak Kekayaan Intelektual yang berada di bawah Kementerian Hukum dan HAM.

3. Selama jangka waktu tertentu, artinya paten diberikan tidak untuk selamanya dan hanya berlaku dalam jangka waktu yang terbatas yakni 20 (dua puluh) tahun sejak tanggal penerimaan dan jangka waktu tersebut tidak dapat diperpanjang. Oleh karena itu, hak eksklusif yang diberikan kepada pemegang paten hanya bersifat terbatas. Setelah paten tersebut habis

Nomor 2, April 2006, hal.129.

$10 \quad$ Ibid masa pelindungannya, statusnya berubah menjadi public domain atau menjadi milik umum. Setiap orang dapat memproduksi atau membuat invensi yang telah berakhir pelindungan patennya (Pasal 22 ayat (1) dan ayat (2) UU Paten Tahun 2016).

Paten dalam pengertian hukum adalah hak khusus yang diberikan berdasarkan undang-undang oleh pemerintah kepada orang atau badan hukum yang menghasilkan suatu penemuan (invention) di bidang teknologi. Sehingga si penemu untuk jangka waktu tertentu dapat melaksanakan sendiri penemuannya ataupun melarang pihak lain menggunakan suatu cara mengerjakan atau memuat barang tersebut (method, proces). Paten tersebut diberikan atas dasar permintaan. ${ }^{11}$

Pendaftaran paten adalah proses atau cara dalam melakukan perbuatan hukum untuk mendaftarkan suatu invensinya di bidang teknologi. Setelah paten terdaftar maka akan memperoleh pelindungan hukum. Pelindungan hukum merupakan suatu kepastian hukum yang diberikan kepada seseorang yang membutuhkan untuk mendapatkan rasa aman terhadap kepentingannya ${ }^{12}$.

Terkait dengan PCT, PCT merupakan suatu perjanjian kerjasama paten yang bersifat multilateral, diselenggarakan di Washington pada 19 Juni 1970 dalam suatu konferensi para diplomat dari 78 negara dan 22 organisasi internasional. PCT telah diubah 2 kali yaitu pada tahun 1979 dan tahun 1984. Indonesia sendiri baru meratifikasi PCT pada tahun 1997 melalui Keppres RI No. 16 Tahun 1997. PCT merupakan perjanjian khusus dibawah Konvensi Paris dan perjanjian ini dimaksudkan untuk memfasilitasi dan memberi pelindungan paten di beberapa negara dari anggota Konvensi Paris. Keanggotaan PCT adalah terbuka bagi

11 Mastur, "Perlindungan Hukum Hak Kekayaan Intelektual di Bidang Paten”, Jurnal Ilmu Hukum QISTI, Volume 6 Nomor 1, Januari 2012, hal. 68-69.

12 Edward James Sinaga, "Implikasi Paten Asing Yang Telah Terdaftar Atas Invensi Di Bidang Teknologi Menurut Undang-Undang No. 14 Tahun 2001 Tentang Paten”, Jurnal Ilmiah Kebijakan Hukum, Volume 7 Nomor 1, Maret 2013, hal. 17. 
negara anggota Konvensi Paris, dan hingga tahun 2015 anggotanya menjadi 165 negara. PCT ditujukan untuk penyederhanaan prosedur administratif pendaftaran permintaan paten internasional, seperti filling, searching, dan examining. Agar tujuan PCT tercapai yaitu penyederhanaan proses, maka digunakanlah sistem "single application". Sistem ini memungkinkan sebuah permintaan diajukan secara serentak pada sejumlah negara, dan pengajuan permintaan itu akan menjadi ekuivalensi pengajuan permintaan paten pada masing-masing negara anggota yang dituju, sebagaimana dinyatakan dalam permintaan paten. Permintaan paten internasional cukup diajukan dalam satu bahasa (yang diakui secara internasional), di kantor paten negara asal, dan selanjutnya cukup memenuhi satu ketentuan mengenai persyaratan formalitas ${ }^{13}$. Selain itu, tujuan permohonan internasional paten adalah agar paten tersebut mendapat pelindungan di beberapa negara. Untuk itu si pemohon harus mengajukannya di setiap negara di mana pelindungan tersebut dikehendaki. Dengan demikian setiap kantor paten nasional masingmasing negara harus melaksanakan penelitian terhadap permohonan paten tersebut. Sistem ini tentu banyak memerlukan pekerjaan, waktu dan biaya. Pemecahan permasalahan inilah yang merupakan tujuan dari PCT.

Adapun substansi Regulations under the PCT antara lain membahas mengenai kesepakatan para Negara Pihak terhadap beberapa hal yakni: (a) memberikan kontribusi terhadap kemajuan ilmu pengetahuan dan teknologi, (b) menyempurnakan pelindungan hukum terhadap penemuan, (c) menyederhanakan dan membuat lebih ekonomis dalam memperoleh pelindungan penemuan di mana pelindungan dicari di beberapa negara, (d) mempermudah dan mempercepat akses oleh masyarakat dengan informasi teknis yang terkandung dalam dokumen yang menjelaskan penemuan baru, (e) mendorong dan mempercepat pembangunan ekonomi negara-negara berkembang melalui

13 Ary M. Sigit, Sistem Perlindungan Paten, Makalah Seminar, Kerjasama Ditjen HKI- UNUD, Denpasar, 2000, hal. 3. adopsi dari langkah-langkah yang dirancang untuk meningkatkan efisiensi sistem hukum mereka, baik nasional atau regional, (f) melembagakan pelindungan penemuan dengan memberikan informasi mudah diakses tentang ketersediaan solusi teknologi.

Pengaturan PCT terkait dengan pelindungan paten khususnya terkait dengan permohonan pendaftaran internasional dapat dilihat dalam Artikel 3 PCT dan Regulations under the PCT yang menyatakan:

(1) Applications for the protection of inventions in any of the Contracting States may be filed as international applications under this Treaty.

(2) An international application shall contain, as specified in this Treaty and the Regulations, a request, a description, one or more claims, one or more drawings (where required), and an abstract.

(3) The abstract merely serves the purpose of technical information and cannot be taken into account for any other purpose, particularly not for the purpose of interpreting the scope of the protection sought

(4) The international application shall:

(i) be in a prescribed language;

(ii) comply with the prescribed physical requirements;

(iii) comply with the prescribed requirement of unity of invention;

(iv) be subject to the payment of the prescribed fees.

\section{B. Pengaturan Menurut UU Paten Tahun 2016}

Permohonan pengajuan paten di Indonesia juga dapat dilakukan melalui PCT atau Traktat Kerjasama Paten. Ketentuan tentang permohonan berdasarkan Traktat Kerja Sama Paten diatur dalam Pasal 33 UU Paten Tahun 2016 yang menyatakan bahwa permohonan dapat diajukan berdasarkan Traktat Kerja Sama Paten. Ketentuan ini bermaksud untuk memberikan kemudahan dan kecepatan kepada seoarang pemohon di Indonesia dalam mengajukan permohonanya di luar negeri yang merupakan anggota PCT demikian 
juga sebaliknya bagi anggota dari negara lain yang tergabung dalam PCT sehingga dapat diselesaikan secara mudah dan cepat. Adapun lingkup pelindungan terdiri dari paten dan paten sederhana sebagaimana diatur dalam Pasal 2 UU Paten Tahun 2016. Dengan demikian pelindungan paten dan paten sederhana, dalam pemeriksaan substantif dilakukan dengan penilaian kebaruan (novelty), langkah inventif (inventif steps), dan keterapannya dalam industri (industrial applicable) berdasarkan dokumen pembanding yang ditemukan dari hasil penelusuran (searching), sebagaimana diatur dalam Pasal 2 dan Pasal 3 UU Paten Tahun 2016. Namun untuk paten sederhana tidak diperiksa langkah inventifnya sehingga berbeda perlakuan pemeriksaan substantif antara paten dengan paten sederhana.

Selain itu, pelindungan paten terhadap suatu invensi dapat diberikan salah satunya mengandung unsur kebaruan. Dalam UU Paten Tahun 2001 terhadap invensi yang diumumkan oleh inventornya dalam sidang ilmiah dalam bentuk ujian dan/atau tahap-tahap ujian skripsi, tesis, disertasi dan/atau forum ilmiah lain dalam rangka pembahasan hasil penelitian di perguruan tinggi atau lembaga penelitian tidak dapat didaftarkan paten karena dianggap telah diumumkan sehingga tidak memenuhi unsur kebaruan. Hal tersebut tentunya sangat merugikan inventor terutama yang bekerja di perguruan tinggi. Untuk itu dalam UU Paten Tahun 2016 diberikan pengecualian pengumuman terhadap invensi dalam perguruan tinggi. Sesuai dengan Pasal 6 ayat (1) huruf c UU Paten Tahun 2016, bahwa dikecualikan dari ketentuan sebagaimana dimaksud dalam Pasal 5 ayat (2), invensi tidak dianggap telah diumumkan jika dalam waktu paling lama 6 (enam) bulan sebelum tanggal penerimaan, invensi telah (c) diumumkan oleh inventornya dalam 1) sidang ilmiah dalam bentuk ujian dan/ atau tahap ujian skripsi, tesis, disertasi, atau karya ilmiah lain; dan/atau 2) forum ilmiah lain dalam rangka pembahasan hasil penelitian di lembaga pendidikan atau lembaga penelitian.
Selanjutnya pelindungan terhadap paten diatur dalam Pasal 22 UU Paten Tahun 2016 yang menyatakan paten diberikan untuk jangka waktu selama 20 (dua puluh) tahun terhitung sejak tanggal penerimaan, dan jangka waktu tersebut tidak dapat diperpanjang, kemudian tanggal mulai dan berakhirnya jangka waktu paten dicatat dan diumumkan melalui media elektronik dan/atau media non-elektronik. Pelindungan hukum terhadap suatu paten yang diberikan adalah sama untuk seluruh negara di dunia selama 20 (dua puluh tahun), dan hal ini berlaku secara teritorial sehingga setiap pemohon harus mengajukan permohonan patennya di setiap negara apabila ingin mendapatkan pelindungan. Sedangkan untuk paten sederhana diberikan untuk jangka waktu selama 10 (sepuluh) tahun terhitung sejak tanggal penerimaan, dan jangka waktu tersebut tidak dapat diperpanjang. Tanggal mulai dan berakhirnya jangka waktu paten dicatat dan diumumkan melalui media elektronik dan/ atau media non elektronik. Syarat dan tata cara permohonan paten diatur di dalam Pasal 24 UU Paten Tahun 2016, di mana paten diberikan berdasarkan permohonan yang diajukan oleh pemohon atau kuasanya kepada Menteri secara tertulis dalam Bahasa Indonesia dengan membayar biaya. Permohonan paten harus memuat tanggal, bulan, dan tahun dari surat permohonan, kemudian nama, alamat lengkap, dan kewarganegaraan inventor atau pemohon dalam hal jika pemohon bukan badan hukum, atau nama kuasa jika permohonan diajukan melalui kuasa, seperti diatur di dalam Pasal 25 UU Paten Tahun 2016.

\section{PENERAPAN PATEN}

Sebelum membahas pelindungan paten melalui PCT dan Regulations under the PCT terlebih dahulu dijelaskan konsep atau teori pelindungan hukum. Tahapan pelindungan hukum terdiri dari pelindungan hukum yang lahir dari suatu ketentuan hukum dan segala peraturan hukum yang diberikan oleh masyarakat yang pada dasarnya merupakan 
kesepakatan masyarakat tersebut untuk mengatur hubungan perilaku antara anggotaanggota masyarakat dan antara perseorangan atau badan hukum dengan pemerintah yang dianggap mewakili kepentingan masyarakat. Menurut Satijipto Raharjo, pelindungan hukum adalah memberikan pengayoman terhadap hak asasi manusia (HAM) yang dirugikan orang lain dan pelindungan itu diberikan kepada masyarakat agar dapat menikmati semua hak yang diberikan oleh hukum. ${ }^{14}$

Dengan demikian pelindungan hukum merupakan gambaran dari bekerjanya fungsi hukum untuk mewujudkan tujuan hukum, sehingga dapat memberikan keadilan, kemanfaatan, dan kepastian hukum. Pelindungan hukum dilekatkan pada suatu paten, sebagai obyek yang terhadapnya terkait hak perseorangan atau badan hukum. Tanpa adanya pelindungan hukum para pesaing dapat melakukan peniruan terhadap paten pihak lain tanpa harus mengeluarkan biaya. A. Zen Umar Purba mengemukakan alasan mengapa HKI perlu dilindungi oleh hukum sebagai berikut: ${ }^{15}$

a. Alasan yang "bersifat non ekonomis" menyatakan, bahwa pelindungan hukum akan memacu mereka yang menghasilkan karya intelektual tersebut untuk terus melakukan kreativitas intelektual. Hal ini akan meningkatkan self actualization pada diri manusia. Bagi masyarakat hal ini akan berguna untuk meningkatkan perkembangan hidup mereka.

b. Alasan yang "bersifat ekonomis", yaitu untuk melindungi mereka yang melahirkan karya intelektual, berarti yang melahirkan karya tersebut mendapat keuntungan materiil dari karyanya. Di lain pihak melindungi mereka dari adanya peniruan, pembajakan, penjiplakan maupun perbuatan curang lainnya yang dilakukan oleh orang lain atas karya-karya yang berhak.

14 Satjipto Rahardjo, Ilmu Hukum, Bandung: PT Citra Aditya Bakti, 2000, hal. 53.

15 Anne Gunawati, Pelindungan Merek Terkenal Barang dan Jasa Tidak Sejenis Terhadap Persaingan Usaha Tidak Sehat, Bandung:, PT. Alumni 2015, hal. 83.
Dengan demikian pelindungan hukum terhadap paten menjadi salah satu aspek penting dalam sistem PCT dan Regulations under the PCT. Suatu paten sudah seharusnya dilindungi karena dapat memicu pihak yang tidak bertanggung jawab untuk secara illegal melakukan pelanggaran terhadap suatu paten yang telah terdaftar. Konsep pelindungan hukum terhadap pemegang paten bersifat khusus (exclusive). Hak eksklusif artinya hak yang hanya diberikan kepada pemegang paten untuk jangka waktu tertentu guna melaksanakan sendiri secara komersial atau memberikan hak lebih lanjut kepada orang lain. Dengan demikian, orang lain dilarang melaksanakan paten tanpa persetujuan pemegang paten. Hak eksklusif merupakan hak khusus dari subyek hukum baik orang atau korporasi untuk menggunakan suatu hak kebendaan atau melaksanakan suatu kegiatan. Hak eksklusif dalam pelindungan hak paten merupakan hak kebendaan yang bersifat tidak berwujud (intangible), juga hak monopoli terhadap penggunaan atau pemanfaatannya. Hak monopoli dalam pelindungan paten memiliki makna bahwa tidak setiap orang dapat menggunakan hak invensi tersebut atau malaksanakan haknya. Penggunaan atau pelaksanaan hak tersebut harus mendapatkan ijin dari pemegang hak paten melalui lisensi.

Paten merupakan suatu pemberian (grand) oleh negara berupa hak untuk melarang pihak lain untuk menggunakan/membuat/menjual invensi, dan negara memberi pengakuan secara hukum dalam bentuk hak ekonomi dan hak moral untuk kreasi inventor. Dengan demikian hanya inventor yang mempunyai akses dan pengakuan dari negara. Asas ini telah diterapkan di dalam UU Paten Tahun 2016, yang mengatur pemegang paten memiliki hak eksklusif untuk melaksanakan paten yang dimilikinya dan melarang pihak lain yang tanpa persetujuannya. Dalam hal paten-produk, hak eksklusif tersebut untuk membuat, menggunakan, menjual, mengimpor, menyewakan, menyerahkan, atau menyediakan untuk dijual atau disewakan atau diserahkan produk yang diberi paten. Dalam hal paten-proses, hak eksklusif tersebut untuk 
menggunakan proses produksi yang diberi paten untuk membuat barang dan tindakan lainnya. Dalam hal paten-proses, larangan terhadap pihak lain yang tanpa persetujuannya melakukan impor hanya berlaku terhadap impor produk yang semata-mata dihasilkan dari penggunaan paten-proses yang dimilikinya. Pengecualian diberikan apabila pemakaian paten tersebut untuk kepentingan pendidikan, penelitian, percobaan, atau analisis sepanjang tidak merugikan kepentingan yang wajar dari pemegang paten. Secara umum tahap internasional dilakukan dalam waktu kurang lebih 30 (tiga puluh) bulan sejak tanggal prioritas. Tujuan pendaftaran internasional paten adalah agar paten tersebut mendapat pelindungan di beberapa negara. Untuk itu si pemohon harus mengajukan di setiap negara di mana pelindungan tersebut dikehendaki. Dalam tahap internasional dilakukan proses penelusuran secara internasional melalui International Search Authority (ISA) serta proses publikasi sebelum memasuki tahap national. Sedangkan pendaftaran paten dalam tahap nasional merupakan tahap pendaftaran paten tersebut di negara tujuan. Namun, diterima atau tidaknya paten tersebut di negara tujuan merupakan hak prerogatif dari masing-masing negara tujuan.

Paten menganut prinsip teritorial, artinya pelindungan paten hanya berlaku di negara di mana permohonan paten diajukan dan diberi. Terkait dengan permohonan paten, berdasarkan hasil wawancara yang dilakukan dengan Kepala Lembaga Pengembangan Inovasi dan Kewirausahaan (LPIK) Institut Teknologi Bandung ${ }^{16}$, sebelum mengajukan permohonan paten, inventor terlebih dahulu melaksanakan penelusuran (search), untuk memperoleh gambaran apakah invensi yang diajukan memang memenuhi syarat kebaruan, artinya belum pernah ada pengungkapan sebelumnya oleh siapapun, termasuk oleh inventor sendiri. Penelusuran dapat dilakukan

Hasil wawancara dengan Kepala Lembaga Pengembangan Inovasi dan Kewirausahaan (LPIK) Institut Teknologi Bandung dalam rangka Penelitian tentang Pelindungan Paten Melalui PCT, Institut Teknologi Bandung, 13 Juni 2016. terhadap dokumen paten baik yang tersimpan pada database Ditjen HKI, maupun kantor paten lain di luar negeri yang representatif dan juga relevan terhadap teknologi dari invensi yang akan dipatenkan; dan juga terhadap dokumen-dokumen non-paten seperti jurnal ilmiah yang terkait. Penelusuran paten bahkan sangat disarankan untuk dilakukan sebelum rencana penelitian terhadap suatu teknologi dilaksanakan untuk melakukan technology mapping berdasarkan dokumen paten yang tersedia, sehingga penelitian bisa dilakukan secara lebih efektif dan efisien.

Dengan demikian keharusan pendaftaran paten melalui PCT hanya berlaku pada negara anggota penandatanganan PCT, Sebaliknya bagi pemohon paten dari negara lain yang juga merupakan anggota PCT dapat melakukan permohonan pendaftaran paten di Indonesia. Permohonan pendaftaran paten melalui PCT mempunyai akibat sebagaimana halnya permohonan paten nasional di setiap negara anggota PCT. Pengajuan permohonan pendaftaran internasional yang sesuai dengan sistem PCT, permohonan tersebut diperiksa untuk kebaruan dengan mencari paten sebelumnya dengan teknis literatur sebelum selanjutnya disampakan kepada kantor paten nasional di setiap negara yang dituju.

Setelah dilakukan penelusuran dan dapat diyakini bahwa invensi yang akan dipatenkan masihmengandungkebaruan, langkahselanjutnya adalah membuat spesifikasi paten yang terdiri atas sekurang-kurangnya: (a) Judul Invensi; (b) Latar Belakang Invensi, yang menerangkan teknologi yang ada sebelumnya serta masalah yang terdapat pada teknologi tersebut, yang coba ditanggulangi oleh invensi; (c) Uraian Singkat Invensi, yang menerangkan secara ringkas mengenai fitur-fitur yang terkandung dalam, dan menyusun, invensi; (d) Uraian Lengkap Invensi, yang menerangkan mengenai bagaimana cara melaksanakan invensi; (e) Gambar Teknik, jika diperlukan untuk menerangkan invensi secara lebih jelas; (f) Uraian Singkat Gambar, untuk menerangkan mengenai Gambar Teknik yang disertakan; (g) Abstrak, ringkasan 
mengenai invensi dalam satu atau dua paragraf; (h) Klaim, yang memberi batasan mengenai fitur-fitur apa saja yang dinyatakan sebagai baru dan inventif oleh sang inventor, sehingga layak mendapatkan hak paten. Penyusunan spesifikasi paten membutuhkan keahlian dan pengalaman tersendiri, karena perlu memadukan antara bahasa teknik dan bahasa hukum di dalamnya. Apabila ketiga persyaratan minimum ini dipenuhi, maka pemohon akan mendapat tanggal penerimaan (filing date). Setelah masa pemeriksaan dilalui dan seluruh persyaratan formalitas dinyatakan lengkap, maka tahap berikutnya adalah pengumuman. Memasuki masa pengumuman ini permohonan paten akan dimuat dalam Berita Resmi Paten dan media resmi pengumuman paten lainnya. Tujuannya adalah membuka kesempatan kepada masyarakat untuk mengetahui mengenai invensi yang dimohonkan paten, di mana masyarakat bisa mengajukan keberatan secara tertulis kepada Ditjen HKI jika masyarakat mengetahui bahwa invensi tersebut tidak memenuhi syarat untuk dipatenkan. Segera setelah masa pengumuman berakhir, atau selambat-lambatnya 30 (tiga puluh enam) bulan terhitung sejak tanggal penerimaan, pemohon dapat mengajukan permohonan pemeriksaan substantif dengan menyerahkan formulir yang telah dilengkapi dan membayar biaya ke Ditjen HKI. Jika pemohon tidak mengajukan Permohonan Pemeriksaan Substantif dalam batas waktu 30 (tigapuluh) bulan dari tanggal penerimaan tersebut, maka permohonannya akan dianggap ditarik kembali dan dengan demikian invensinya menjadi public domain ${ }^{17}$.

Dalam Tahap Pemeriksaan Substantif inilah DJHKI melalui pemeriksa paten akan menentukan apakah invensi yang dimohonkan paten tersebut memenuhi syarat substantif sehingga layak diberi paten, berdasarkan dokumen pembanding baik dokumen paten maupun non-paten yang relevan. Dalam waktu paling lambat 30 bulan sejak Permohonan Pemeriksaan Substantif diajukan, pemeriksa paten sudah harus memutuskan apakah akan menolak ataupun memberi paten. Pemohon yang permohonan patennya ditolak dapat mengajukan banding ke Komisi Banding Paten, yang dapat berlanjut ke Pengadilan Niaga hingga akhirnya kasasi ke Mahkamah Agung. Jika pemohon menerima penolakan, ataupun upaya hukum yang diajukannya tetap berujung pada penolakan, maka invensi tersebut menjadi public domain. Terhadap invensi yang diberi paten, DJHKI akan segera mengeluarkan Sertifikat Hak Paten. Dengan demikian pelindungan paten dibuktikan dengan dikeluarkannya sertifikat paten yang berlaku surut sejak tanggal penerimaan.

Sedangkan peranan PCT terkait dengan pelindungan paten, yaitu melalui sistem PCT memungkinkan pemegang paten untuk mendapatkan perlindungan paten atas suatu invensi di sejumlah negara dengan cara mengajukan permohonan paten internasional. Permohonan tersebut dapat diajukan oleh siapa saja yang merupakan warga atau penduduk dari negara peserta. Pada umumnya, permohonan dapat diajukan ke kantor paten nasional atau regional dari negara peserta dimana orang yang mengajukan permohonan menjadi warga atau penduduknya. Selain itu permohonan dapat pula diajukan secara langsung ke Biro Internasional World Intellectual Property Organization (WIPO) di Jenewa, Swiss. PCT dibuat untuk mengatasi masalah yang sering timbul dalam sistem paten nasional. Masalah tersebut antara lain dalam sistem paten nasional suatu permohonan paten harus diajukan ke setiap negara dimana perlindungan paten ingin didapatkan (kecuali untuk sistem paten regional). Selain itu dalam sistem paten nasional pemeriksaan formal dari suatu permohonan paten yang diajukan di suatu negara harus dilakukan oleh Kantor Paten dari negara tersebut. Kantor Paten suatu negara juga harus memeriksa masalah substantif dari suatu permohonan paten, melakukan penelusuran untuk menentukan dokumen pembanding dalam bidang teknik dari invensi yang terkait dan harus melakukan pemeriksaan mengenai patentabilitas dari permohonan tersebut. 
Adapun prosedur PCT meliputi ${ }^{18}$ :

a. Pengarsipan, pemilik paten mengajukan permohonan internasional dengan Kantor Paten nasional atau regional atau WIPO, sesuai dengan persyaratan formalitas PCT, dalam satu bahasa, dan pemilik paten membayar satu set biaya.

b. Penelusuran Internasional, Otoritas Pencarian Internasional (ISA) merupakan salah satu kantor paten terkemuka di dunia yang mengidentifikasi dokumen paten dan literatur teknis yang diterbitkan ("prior art") yang mungkin berpengaruh pada apakah suatu penemuan dapat dipatenkan, dan menetapkan pendapat tertulis tentang potensi paten.

c. Publikasi Internasional, sesegera mungkin setelah berakhirnya 18 bulan sejak tanggal pengajuan paling awal, isi dari aplikasi internasional pemilik paten diungkapkan kepada dunia.

d. Pencarian internasional tambahan (opsional), sebuah ISA kedua mengidentifikasi, atas permintaan pemilik paten, menerbitkan dokumen yang mungkin tidak ditemukan oleh ISA pertama yang melakukan pencarian utama karena keragaman prior art dalam bahasa yang berbeda dan bidang teknis yang berbeda.

e. Pemeriksaan Pendahuluan Internasional (opsional), salah satu ISA atas permintaan pemilik paten, melakukan analisis paten tambahan, biasanya pada versi yang telah diubah dari aplikasi.

Berdasarkan hasil wawancara dengan Kepala LPIK ITB ${ }^{19}$ menyatakan bahwa dalam praktiknya untuk pengajuan permohonan paten melalui PCT di Indonesia meliputi paten dan paten sederhana dan ini berbeda dalam praktik negara maju pengajuan permohonan

18 Hasil FGD dengan Pejabat Ditjen HKI, Kementrian Hukum dan HAM dalam rangka Penelitian tentang Pelindungan Paten Melalui PCT pada Pusat Penelitian Badan Keahlian DPR RI, tanggal 4 April 2016.

19 Hasil wawancara dengan Kepala Lembaga Pengembangan Inovasi dan Kewirausahaan (LPIK) ITB dalam rangka Penelitian tentang Pelindungan Paten Melalui PCT, Institut Teknologi Bandung, 13 Juni 2016. yang dilakukan melalui PCT hanya untuk paten. Khusus pelindungan hukum dalam bentuk paten sederhana, pemeriksaan Langkah Inventif tidak dilakukan, kemudian yang dapat dikabulkan sama dengan paten, yaitu produk atau proses namun hanya 1 (satu) invensi saja akan tetapi dapat terdiri dari beberapa klaim.

PCT mempunyai satu kelebihan yaitu mempersingkat prosedur yang berkaitan dengan permohonan paten nasional dan regional serta hak paten. Implikasi lain dari pengesahan PCT berdampak pada dunia usaha dari kalangan perusahaan multinasional sampai skala kecil akan menikmati keuntungan dari aset hak atas kekayaan intelektual (HaKI) seperti paten dan bersaing di pasar global. Berdasarkan data dari WIPO, perusahaan yang paling banyak menggunakan fasilitas PCT untuk mendapat perlindungan hukum paten secara internasional adalah Koninklijke Philips Electronics N.V, Siemens Aktiengesellschaft, Robert Bosch $\mathrm{GmbH}$, Telefonaktiebolaget Ericsson, Matsushita Electric Industrial Co. Sony Corporation, Nokia Corporation. WIPO telah merancang satu sistem global untuk memfasilitasi mendapatkan pelindungan paten di banyak negara melalui PCT, tapi fasilitas tersebut hingga kini masih didominasi oleh negara maju. Indonesia tampaknya masih jauh di urutan bawah jika dibandingkan dengan negara berkembang lain yang menjadi anggota PCT. Hanya permintaan paten dari India dan Korsel yang cenderung meningkat. Hal itu menunjukkan bahwa penemuan teknologi di kedua negara tersebut berkembang pesat, sedang Indonesia masih jauh di belakang. ${ }^{20}$

Tingginya permintaan pelindungan internasional atas paten melalui PCT menunjukkan indikasi kuat bahwa fasilitas jasa tersebut berguna dan membantu kalangan pengusaha atau inventor (penemu) individu. Indonesia hendaknya lebih gencar melakukan promosi kepada para penemu dari kalangan swasta ataupun individu di dalam negeri

\footnotetext{
"Untuk dapatkan Paten Internasional, PCT buka jalan bagi negara berkembang”, http://www.haki.lipi.go.id/ utama.cgi?cetakartikel\&1113176773, diakses tanggal 5 Januari 2017.
} 
tentang fasilitas PCT itu.Tanpa upaya tersebut, maka fasilitas PCT hanya akan dimanfaatkan oleh negara maju, yang notabena memiliki akses informasi ke lembaga tersebut.

Terkait penerapan PCT, berdasarkan hasil wawancara yang dilakukan dengan inventor dari LPIK ITB menyatakan ${ }^{21}$, dalam penerapannya inventor bebas memilih cara untuk mendaftarkan paten di luar negeri apakah melalui fasilitas PCT di Jenewa atau langsung ke negara yang dituju. Selama ini inventor dari Indonesia biasanya mengajukan permohonan langsung ke negara yang dituju, sehingga patennya tidak tercatat melalui PCT. Sebagai contoh ada inventor dari Indonesia menemukan teknologi di bidang elektronika. Setelah mereka menemukan teknologi tersebut, mereka ditarik oleh perusahaan telekomunikasi Singapura dan paten temuan orang Indonesia itu didaftarkan di Singapura dan apabila inventor tersebut menginginkan pelindungan paten hanya di Amerika Serikat bisa langsung mengajukan permohonan ke negara tersebut. Namun, apabila inventor ingin mendapatkan pelindungan patennya di banyak negara, pilihannya adalah melalui fasilitas PCT.

Dengan demikian mendapatkan pelindungan paten internasional di banyak negara melalui fasilitas PCT lebih mudah dan efisien bila dibandingkan dengan mengajukan permohonan ke setiap negara. Dengan hanya mengajukan satu permohonan perlindungan internasional paten melalui PCT, maka inventor atau kalangan pengusaha swasta Indonesia bisa mendapatkan pelindungan hukum atas patennya di banyak negara sesuai dengan keinginan pemohon dengan syarat negara tersebut harus anggota PCT. Dengan fasilitas PCT, biaya yang dikeluarkan untuk mendapatkan pelindungan internasional atas paten di banyak negara relatif murah serta hemat dari segi waktu bila dibandingkan individu atau pengusaha swasta mengajukan permohonan perlindungan paten ke masing-

21 Hasil wawancara dengan Kepala Lembaga Pengembangan Inovasi dan Kewirausahaan (LPIK) ITB dalam rangka Penelitian tentang Pelindungan Paten Melalui PCT, Institut Teknologi Bandung, 13 Juni 2016. masing negara. Semua fasilitas dan sarana sudah tersedia, tinggal memanfaatkannya, mengingat Indonesia sudah relatif lama menjadi anggota PCT. Namun apabila pemilik paten cuma meminta pelindungan paten hanya di satu atau dua negara saja, maka fasilitas itu kurang tepat karena biayanya relatif lebih mahal. Bagi Indonesia, fasilitas PCT ini menguntungkan karena akan memacu permintaan paten asing ke dalam negeri. Indonesia akan mendapat fee dari setiap paten asing yang meminta perlindungan hukum ke Indonesia.

Terkait dengan perlindungan paten, hasil wawancara yang dilakukan dengan Kepala LPIK ITB menyatakan ${ }^{22}$, secara umum pelindungan paten dapat dimohonkan segera setelah semua informasi yang diperlukan untuk merancang permohonan paten diperoleh. Namun demikian, terdapat beberapa faktor yang dapat membantu pemohon dalam memutuskan kapan waktu terbaik untuk melakukan permohonan paten. Permohonan paten sebaiknya dilakukan lebih awal karena:

a. Paten diberikan dengan dasar first-to-file. Dengan demikian melakukan permohonan lebih awal sangat dianjurkan guna menjamin bahwa si pemohon adalah pemohon pertama yang melakukan permohonan untuk invensi tersebut sehingga invensi tersebut tidak menjadi milik orang lain;

b. Melakukan permohonan lebih awal biasanya akan sangat bermanfaat apabila ingin mendapatkan dukungan finansial atau ingin melisensikan invensi tersebut untuk dikomersialisasikan;

c. Secara umum paten dapat dipertahankan setelah paten tersebut diberikan oleh Kantor HKI yang berkaitan, yang prosedurnya membutuhkan waktu beberapa tahun.

Namun demikian terburu-buru melakukan permohonan paten ketika memiliki invensi tersebut dapat juga menimbulkan permasalahan dengan karena:

22 Hasil FGD dengan Pejabat Lembaga Pengembangan Inovasi dan Kewirausahaan (LPIK) ITB dalam rangka Penelitian tentang Pelindungan Paten Melalui PCT, Institut Teknologi tanggal 14 Juni 2016. 
a. Apabila melakukan permohonan terlalu dini dan selanjutnya membuat perubahan pada invensi tersebut maka perubahan yang terlalu signifikan tidak mungkin dilakukan terhadap deskripsi asli dari invensi tersebut.

b. Apabila sebuah invensi sudah dimohonkan pada satu negara atau kawasan tertentu, biasanya terdapat waktu selama 12 bulan untuk melakukan permohonan untuk invensi yang sama pada semua negaranegara tujuan bisnis guna mendapatkan manfaat dari tanggal permohonan dari permohonan yang pertama tersebut. Hal ini bisa menjadi masalah jika biaya permohonan di berbagai negara tersebut bervariasi dan biaya pemeliharaannya terlalu tinggi bagi perusahaan pemilik invensi. Satu cara untuk menyiasati permasalahan ini adalah dengan menunda pembayaran biaya penterjemahan dan biaya resmi untuk jangka waktu selama 30 (tiga puluh) bulan dengan menggunakan PCT.

Dengan demikian, dalam penerapan ketentuan atau cara tersebut di Indonesia memang tidak semudah membalikkan telapak tangan karena untuk menerapkan ketentuan atau cara tersebut harus diselaraskan dengan ketentuan yang berlaku di Indonesia. Dalam prakteknya segala sesuatu walaupun sudah direncanakan secara matang dapat mengalami kendala dalam pelaksanaan prakteknya. ${ }^{23}$

Berdasarkan data usulan karya terdapat 39 karya telah didaftarkan paten, 38 buah berasal dari ITB baik melalui program bantuan ITB maupun bantuan dari luar seperti UBER HaKI (Dikti) dan OLEH PATEN (KMNRT). Dari data tersebut hanya satu penemuan yang dilakukan permohonan melalui PCT di Malaysia yakni penemuan mengenai Refrigeran Hidrokarbon Pengganti CFC 12 Tak Mudah Terbakar. Perlu dicatat, terdapat kemungkinan bahwa tidak semua usulan paten tersebut berhasil (granted) ${ }^{24}$ :

\footnotetext{
23 Agus Riswandi dan M.Syamsudin, Hak Kekayaan Intelektual dan Budaya Hukum, Jakarta: PT. Raja Grafindo Persada, 2004, hal. 131

$24 \quad$ Ibid.
}

Permohonan melalui PCT, yaitu rute internasional untuk pengajuan permohonan paten, digunakan ketika pemohon ingin mengajukan permohonan di banyak negara sekaligus dengan segera. Dengan melalui PCT, pemohon dapat mengajukan permohonan di hampir semua negara anggota PCT dan keputusan untuk menentukan negara yang benar-benar ingin diperoleh patennya dapat diputuskan kemudian. Pemilik HKI harus mempertimbangkan bahwa tidak hanya biaya pendaftaran yang tinggi tetapi juga biaya selanjutnya. Biaya dapat dikurangi dengan menimbang negara mana yang akan dikecualikan sebelum pendaftaran. Pemohon HKI harus memahami sepanjang mereka konsisten mengembangkan penemuan, maka ide teknis dan perbaikan berikutnya dapat dikemukakan dalam klaim dan deskripsi melalui permohonan baru yang pada permohonan terdahulu belum ada.

Terkait dengan struktur sebuah permohonan paten, dari hasil wawancara yang dilakukan dengan Nursaulina Siregar, Paten Drafter, Sentra HKI Lotus Balitbang Provinsi Sumatera Selatan menyatakan ${ }^{25}$, bahwa sebuah permohonan paten memiliki beberapa fungsi yakni untuk menentukan cakupan hukum dari paten yang berkaitan, menerangkan sifat dari invensi termasuk instruksi bagaimana cara mengoperasikan invensi tersebut; dan memberikan rincian mengenai inventor, pemilik paten dan informasi hukum lainnya. Permohonan paten di seluruh dunia memiliki struktur yang mirip yang terdiri dari sebuah permohonan, sebuah deskripsi, klaim, gambar dan sebuah abstrak. Sebuah dokumen paten memiliki ketebalan dan jumlah halaman berkisar dari beberapa halaman saja sampai ratusan halaman bergantung pada sifat dari invensi spesifik dan bidang teknisnya.

Selain itu, dari hasil wawancara yang dilakukan dengan Kanwil Hukum dan HAM

\footnotetext{
25 Hasil wawancara dengan Nursaulina Siregar, Paten Drafter, dalam rangka Penelitian tentang Pelindungan Paten Melalui PCT, Sentra HKI Lotus Balitbang Provinsi Sumatera Selatan, 10 Agustus 2016.
} 
Provinsi Jawa Barat $^{26}$, untuk penyederhanaan sistem pendaftaran agar efektif dan lebih efisien, dapat dilakukan dengan cara membentuk sistem pendaftaran internasional yang memungkinkan pengajuan paten melalui satu kantor paten (Receiving Office), dengan satu permohonan dalam satu bahasa dan mempunyai efek pada setiap negara anggota PCT (Designated States), menyediakan pemeriksaan formal dari permohonan paten internasional oleh satu Kantor Paten, yaitu Receiving Office (R0), dilakukan penelusuran dan pemeriksaan paten yang dapat digunakan sebagai bahan pertimbangan penilaian patentabilitas dan menyediakan publikasi internasional yang disentralisasi bersama dengan hasil penelusurannya (dilakukan oleh ISA).

Peranan PCT terkait dengan pelindungan paten, di samping mempunyai keuntungan namun juga terdapat beberapa kendala ${ }^{27}$, pertama, PCT hanya merupakan suatu bentuk kerja sama beberapa negara dengan tujuan memberikan kemudahan dan kecepatan kepada pemohon paten di suatu negara yang akan mengajukan permohonannya ke beberapa negara lain (yang juga anggota PCT). Namun, pendaftaran PCT di negara asal tidak serta merta melindungi paten itu di negara anggota PCT lainnya. Paten yang telah terdaftar di negara asal tersebut tetap harus didaftarkan di Indonesia untuk mendapatkan pelindungan secara hukum.

Kedua, secara umum, pendaftaran paten melalui PCT hanya memberikan kemudahan secara administratif. Sebagai suatu pendaftaran internasional, permohonan PCT dapat diajukan dalam satu bahasa, meskipun terkadang diperlukan proses terjemahan dalam pelaksanaan penelusuran dan publikasi internasional yang disesuaikan dengan jenis

26 Hasil wawancara dengan Kanwil Hukum dan HAM dalam rangka Penelitian tentang Pelindungan Paten Melalui PCT, Kanwil Hukum dan HAM, Provinsi Jawa Barat, 16 Juni 2016.

27 Hasil FGD dengan Pejabat Ditjen HKI, Kementrian Hukum dan HAM dalam rangka Penelitian tentang Pelindungan Paten Melalui PCT, Pusat Penelitian Badan Keahlian DPR RI, tanggal 4 April 2016. bahasa yang digunakan oleh ISA yang ditunjuk. Ketiga, International Pleminary Examination Report (IPER) yang diterbitkannya tidak bersifat mengikat. Dengan demikian hak untuk menolak atau mengabulkan permohonan permintaan paten tetap berada di negara masing-masing. Artinya, tidak otomotis setelah mendapatkan IPER, maka negara dimana kita minta pelindungan paten akan mengabulkannya, semua berpulang kepada negara masing-masing.

Keempat, permohonan paten melalui PCT menjadi perhatian para praktisi HKI, bahwa permohonan paten dari luar negeri melalui konsultan paten lokal kini berkurang, karena dengan PCT permohonan paten untuk berbagai negara dapat dilakukan melalui Biro Internasional WIPO di Jenewa, sehingga peranan konsultan paten lokal otomatis berkurang. Namun dengan adanya UU Paten Tahun 2016 kendala tersebut sudah diatasi karena berdasarkan UU tersebut pendaftaran paten dari luar dilakukan melalui konsultan lokal. Kelima, sosialisasi fasilitas PCT kepada orang Indonesia belum efektif, sengketa yang timbul dalam perjanjian pengalihan paten, riset yang diselenggarakan belum berorientasi kepada paten, tingkat kesiapan aparat penegak hukum dinilai belum sepenuhnya mampu mengimplementasikan UU Paten Tahun 2016 secara optimal. Dengan demikian kurangnya sosialisasi mengakibatkan kecilnya jumlah permohonan paten asal Indonesia melalui PCT karena ketidaktahuan orang Indonesia terhadap fasilitas tersebut. Selain kurangnya sosialisasi fasilitas PCT mengakibatkan para inventor belum mengetahui langkah-langkah dan bagaimana caranya mendaftarkan paten melalui PCT. Oleh karena itu, pemerintah diharapkan lebih aktif melakukan sosialisasi soal keberadaan fasilitas PCT kepada para inventor di dalam negeri, temasuk kepada litbang perguruan tinggi dan litbang departemen. Selain kendala terkait dengan peranan PCT, juga terdapat beberapa kendala diantaranya terkait dengan upaya untuk menghasilkan paten yakni lemahnya perhatian pemerintah dan kurangnya lembaga donor yang bersedia 
menyokong seorang peneliti untuk melakukan dan mengembangkan penelitian di negeri sendiri.

\section{PENUTUP}

Pengaturan pelindungan paten melalui PCT dan Regulation under the PCT mengatur pelindungan paten melalui pendaftaran paten sebagai sarana pelindungan hukum. Pengaturan pelindungan paten melalui hukum internasional terkait dengan PCT, khususnya yang telah diratifikasi oleh Indonesia terdapat dalam beberapa konvensi internasional yakni antara lain pengaturan TRIPs, PCT dan WIPO. Pengaturan PCT terkait dengan pelindungan paten khususnya terkait dengan permohonan pendaftaran internasional dapat dilihat dalam Artikel 3 PCT dan Regulation under the PCT. Sedangkan dalam hukum nasional pengaturan tentang permohonan berdasarkan Traktat Kerja Sama Paten diatur dalam Pasal 33 UU Paten Tahun 2016 yang menyatakan permohonan dapat diajukan berdasarkan Traktat Kerja Sama Paten. Ketentuan tersebut dimaksudkan dalam rangka memberikan kemudahan dan kecepatan kepada seoarang pemohon di Indonesia dalam mengajukan permohonannya di luar negeri yang merupakan anggota PCT demikian juga sebaliknya bagi anggota dari negara lain yang tergabung dalam PCT sehingga dapat diselesaikan secara mudah dan cepat. Adapun lingkup pelindungan terdiri dari paten dan paten sederhana.

Penerapan pelindungan paten melalui PCT hanya diberlakukan terhadap paten yang telah didaftarkan dan pendaftaran di negara asal tidak serta merta melindungi paten tersebut di negara anggota PCT lainnya. Paten yang telah terdaftar di negara asal tersebut tetap harus didaftarkan di Indonesia untuk mendapatkan pelindungan secara hukum. Secara umum, pendaftaran paten melalui PCT hanya memberikan kemudahan secara administratif. Permohonan pendaftaran paten melalui PCT di negara tujuan (receiving office) dilakukan dalam waktu maksimum 12 (dua belas) bulan sejak tanggal prioritas (tanggal pertama kali diajukannya paten tersebut di negara asal (designated office) dan dapat dilakukan melalui kantor paten di negara asal tersebut tanpa harus melakukan pendaftaran secara langsung ke negara tujuan. Proses pendaftaran paten melalui PCT terbagi menjadi 2 (dua) tahap, yaitu tahap internasional (international phase) dan tahap nasional (national phase). Adapun kendala terkait dengan peranan PCT yakni antara lain pengenalan masyarakat terhadap system PCT terkait pelindungan paten atau pemahaman akan pentingnya pelindungan paten sangat rendah. Hal ini dipengaruhi oleh ketidaksiapan institusi yang masih menempatkan prioritas pemasyarakatn HaKI di tingkat bawah. Kendala lainnya sosialisasi fasilitas PCT kepada orang Indonesia belum efektif, sengketa yang timbul dalam perjanjian pengalihan paten, riset yang diselenggarakan belum berorientasi kepada paten, kualitas perangkat perundangundangan, tingkat kesiapan aparat penegak hukum dinilai belum sepenuhnya mampu mengimplementasikan Undang-Undang Paten Tahun 2016 secara optimal.

\section{A. Saran}

Perlu dilakukan harmonisasi hukum (law/ legal harmonization) dan koordinasi kelembagaan antara Ditjen HKI dan BIRPI agar paten yang didaftarkan di Indonesia juga dapat didaftarkan di BIRPI sehingga paten Indonesia terlindungi secara internasional.

\section{DAFTAR PUSTAKA}

\section{Jurnal}

Firdaus. "Kedudukan Hukum Internasional Dalam Sistem Perundang-undangan Nasional Indonesia”. Fiat Justisia. Jurnal Ilmu Hukum. Volume 8 Nomor 1, JanuariMaret 2014. 
Hidayah, Khoirul. "Perlindungan Hak Paten

Dalam Kajian Hukum Islam dan Peran Umat Islam Dalam Bidang IPTEK". De Jure. Jurnal Syariah dan Hukum. Volume 4 Nomor 1. Fakultas Syariah UIN Maliki Malang, Juli 2012.

James Sinaga, Edward. "Implikasi Paten Asing Yang Telah Terdaftar Atas Invensi Di Bidang Teknologi Menurut UndangUndang No. 14 Tahun 2001 Tentang Paten". Jurnal Ilmiah Kebijakan Hukum. Volume 7 Nomor 1, Maret 2013.

Mastur, "Perlindungan Hukum Hak Kekayaan Intelektual di Bidang Paten". Jurnal Ilmu Hukum QISTI, Volume 6 Nomor 1, Januari 2012.

Nasir, Rinayah. "Paten Dalam Proses Produksi: Tinjauan Hak Yang Melekat pada Inventor". Jurnal Hukum POSITUM, Volume 1 Nomor 1, Desember 2016.

Purwaningsih, Endang, "Paten Sebagai Konstruksi Hukum Perlindungan Terhadap Invensi Dalam Bidang Teknologi dan Industri". Jumal Hukum Pro Justitia. Volume 24 Nomor 2, April 2006.

Patrick Tuuk, Wilsen. "Perlindungan Hak Kekayaan Intelektual (HKI) Terhadap Pengetahuan dan Teknologi Tradisional Menurut Undang-Undang No.13 Tahun 2016 Tentang Paten”. Jurnal Lex Privatum. Volume V Nomor 4, Juni 2017.

\section{Buku}

Dumoli Agusman, Damo. Treaties Under Indonesian Law: A Comparative Study. Jakarta: Remaja Rosdakarya. 2014.
Dirdjosiswono, Soedjono. Hukum Perusahaan Mengenai Hak Atas Kekayaan Intelektual (Hak Cipta, Hak Paten, Hal Merek). Bandung: Mandar Maju, 2000.

Anne Gunawati. Pelindungan Merek Terkenal Barang dan Jasa Tidak Sejenis Terhadap Persaingan Usaha Tidak Sehat. Bandung: PT. Alumni, 2015.

Haryanto, Ignatius. Penghisapan Rezim HaKI, Tinjauan Ekonomi Politik Terhadap HAKI. Jakarta: Kreas Wacana, 2002.

M. Sigit, Ary. Sistem Perlindungan Paten. Makalah Seminar. Kerjasama Ditjen HKIUNUD. Denpasar, 2000.

Riswandi, Agus dan M. Syamsudin. Hak Kekayaan Intelektual dan Budaya Hukum. Jakarta: PT. Raja Grafindo Persada, 2004.

Rahardjo, Satjipto. Ilmu Hukum. Bandung: PT Citra Aditya Bakti, 2000.

\section{Website}

"Peranan Patent Cooperation Treaty (PCT) dalam Permohonan Paten di Indonesia". http://etd.repository.ugm.ac.id/index. php mod $=$ penelitian_detail $\&$ sub $=$ Pene litianDetail\&act $=$ view \& typ $=$ html \&bu ku_ii $=69220$, diakses tanggal 25 Agustus 2017.

"Untuk dapatkan Paten Internasional". PCT buka jalan bagi negara berkembang". http://www.haki.lipi.go.id/utama. cgi?cetakartikel\&1113176773, diakses tanggal 5 Januari 2017. 